\title{
State-led Forest Development and Social Protest in East Nusa Tenggara Province
}

\author{
Didimus Dedi Dhosa ${ }^{1, *}$ \\ ${ }^{1}$ Faculty of Social and Political Sciences, Widya Mandira Catholic University, Kupang \\ * Correspondence author: dedidhosa@unwira.ac.id; phone: +6281326572402
}

\begin{abstract}
This research examines models of social resistances in response to top-down forest governance in the provincial government of East Nusa Tenggara Province, Indonesia. The researcher demonstrates the models of (1) forest management and (2) people's resistance against the regional government. The author found three fundamental problems through the perspectives of the right to the governing authority of the state and social resistance. First, the provincial government monopolise forest management since 1982 for cattle breeding. Instead of offering prosperity to the people, this forest management model excludes the people from the forest and cattle resources. Second, when the signed contract ended, the local residents refused to extend forest management concessions to the provincial government. Third, the refusal by the residents was carried out through various forms of social movements and cultural politics. However, the provincial government mobilised the police, the civil service police, and the armed forces to intimidate the resistant communities.
\end{abstract}

Keywords: state-led forest development; resistance; cultural politics

\section{Introduction}

The history of forest management in Indonesia has lasted since the colonial era (Peluso, 1991). By investigating the colonial history of Java, Peluso divides the historical stages into two parts. First, from the mid 17th century up to 1799 , when Java was under the trading power of VOC. During this period, the Dutch used the negotiation approach to the Javanese kings and nobilities to gain access to the forest. Second is the period of 1814 to 1940, when Java was under the control of the Dutch. During the second period, the forest was managed by the bureaucracy in collaboration with the colonising power. During this period, a new development took place when the Dutch took control of forest resources. The Dutch capitalised on conservation ideology to legitimise their control of land and forest (Peluso, 1991, p. 65). The Dutch integrated Java into their kingdom and controlled it from the Netherlands as they considered the land in Java belonging to them.

Similar to Java, the history of forest management in Timor started with the domination of the rajas and colonial intervention. At that time, Timor was known as the sandalwood producing island that sent its aromatic logs to several countries. It is this sandalwood that had attracted the interest of the Portuguese, the Spaniards, the Dutch, and even the Chinese to get involved in the control and trade of sandalwood (Ardhana, 2005; Ataupah, 1992; Neonbasu, 2016; Ormeling, 1957; Parimartha, 2002; Neonbasu, 2013).

The sandalwood that grew throughout the island of Timor belongs to the ownership of power holders. Therefore, the commoners were not allowed to take the sandalwood without the raja's approval. The Timorese would be punished or fined if the sandalwood trees that grew in their backyard withered away. When the colonial powers terminated, sandalwood trees and the forest were handed over to the provincial government in 1958 when the province was established. Nevertheless, the practice of sandalwood management indicated symptoms of injustice in the profit distribution of sandalwood sales, the case of which was aggravated by state dominance, lack of communication, and lack of people's participation in the sandalwood management' (Raharjo et al., 2013). 
The termination of the colonial era did not put an end to conflicts over the forests of Timor. The monopoly of forest management in Timor transitioned into modern bureaucratic control with actors from the state, private sectors and forest vicinity dwellers. For almost one last decade, conflicts over the forest in Besipae intensify. On the one hand, the government is always adamant about defending its right to forest management at the pretext of cattle breeding and moringa cultivation for the greater prosperity of the people. The government even uses the police forces, the civil service police, and the military to intimidate local residents and demolish their houses. On the other hand, the local residents never give up on wage social protest. They build their grass-root power to convey their objections and rejection against the monopoly of forest management by the government. Local elites and landlords supported their initial struggle, although the provincial government later co-opted the local elites.

This article will describe the monopoly of the Besipae forest management in the South-Central Timor regency by the NTT provincial government and demonstrate in detail the models of people's resistance to the government. Since the contract with Australia ended in 1987, the provincial government took over the right to Besipae forest management for cattle breeding. A good part of the forest area, including the bush area, belongs to the communal ownership of the local people. The problem is that since the termination of the contract, the provincial government prohibits the local people from having access to the forest. This ban of access has triggered the social protests that have been carried out both through street politics and through cultural politics.

A number of studies on the forests in Timor tend to see the local communities as actors who destroy the forest while ignoring the fact that the government plays a significant role in damaging and monopolising forest management. Dako et al. (2018), after conducting a survey and doing a descriptive analysis on the Mutis protected forest in Timor Island, found that 87.45 per cent of firewood consumption comes from the protected forest while the rest of 12.55 per cent comes from residents' farms. These data demonstrate the communities' high dependence on forest products, resulting in deforestation and forest degradation.

Pujiono et al. (2019a) and Pujiono et al. (2019b) utilise the spatial statistical analysis to detect deforestation in the Mutis mountain area during the periods of 1987-1999 and 1999-2017, and by so doing predict the condition of forest in the future based on previous and current data analysis. For them, deforestation is caused by the construction of infrastructure, especially roads, the expansion of farming areas, the cutting of trees, and cultural and institutional activities. Population increases and population density that intensify through the years have also impact deforestation. In the meantime, the tradition of livestock grazing among the Timorese has contributed to reducing forest area. The researchers found that the tropical forest of Mutis mountain has changed significantly in three different periods, namely in 1987, 1999 and 2017, marked by deforestation and forest degradation. In addition, the forest condition worsened by the expansion of agricultural areas and population increase.

Usbobo (2019) believes that the massive forest destruction in Indonesia is caused by the domination of Western formal scientific knowledge. It is necessary to decolonise Western knowledge and make room for local knowledge and practice as an antithesis. In the context of Timor, Usbobo (2019) states that the Atoni Pah Meto or the indigenous Timorese has the Bunuk tradition in the forest management system. However, he does not show in detail how this tradition came into being and survived.

Previous studies tended to question forest destruction by community actions and did not present a detailed resistance paradigm. The studies link deforestation to the increasing number of community members around the forest area, the growing demand for wood, and the construction of roads. Referring to the shortcomings of previous research, this paper seeks to probe the monopoly of forest management by the provincial government for cattle grazing.

This paper argues that it is the government that causes forest destruction. In Besipae, only two important actors took care of forest management since 1982, namely Australia (1982-1987) and the Provincial Offices of Animal Husbandry and Forestry (1987-the 2010s). The government prohibits local people from accessing the forest. As the main actor, the government involved the local 
residents and paid local people in the forest rehabilitation program (Gerhan) that damages the forest.

Forest destruction by the government, be it directly or indirectly, does not occur only in Indonesia but also in other Southeast Asian countries like Cambodia, Thailand and Vietnam (Yasmi et al., 2013). In Cambodia, mining companies got concessions from the Ministry of Industry, Mines and Energy and started their operations in a community forest. With military support, these companies cut down the trees in the customary forests that, in the long run, had produced debris and caused pollution. At the same time, the local residents got compensation neither from the companies nor from the state that had issued concessions. In similar ways, wars waged by the governments had caused deforestation in Colombia (Álvarez, 2003; Landholm et al., 2019), while in the Republic of Congo, social conflicts resulting from mining concessions had caused massive deforestations (Butsic et al., 2015).

The state's disposition that has caused damages to the forest through the issuance of miningconcessions to private companies and war declarations finally positions the state as the enemy that must be opposed through various social protests. The state as the common enemy is a state that facilitates capital gains for political and business circles and not for the benefits of communities living around forests. Such characteristics of the state are signifiers of neoliberal governance that pave the way to capital accumulation (Harvey, 2005).

The government instead promises to involve small communities in forest management to boost welfare in a better direction. Still, it benefits local elites and government elites while keeping small communities away from access to forest resources. The exclusion of local residents from forest areas has led to the bursting out of community resistance in various models of struggle. This paper uses a social movement perspective to explain models of community resistance in the Besipae forest area. Therefore, after presenting the theoretical perspectives of the state's right to control and of social movements, the author will describe the history of forest management, the technicalisation of control, as well as various social protests ranging from street demonstrations to cultural politics that include the formation of customary institutions as a model for political resistance projects.

\section{Theoretical Perspectives}

\subsection{State's right to control}

The state's right to control is the highest principle of the state in the management of natural resources and the whole environment to benefit the entire people of Indonesia. This right is founded upon article 33 of the 1945 Constitution. This legal basis provides an opportunity for the state to take care of the underground resources, waters, and the whole natural life (Rachman, 2017).

From the historical perspective, the state's right to control started in the Sukarno administration, primarily through the Agrarian Fundamental Law of 1960. This law was passed with these three main objectives. First, it is meant to be the basis for national agrarian law that negates the Dutch-inherited regulation that can no longer be applied appropriately in the Indonesian postindependence era. Second, it is meant to terminate the dualism in the colonial agrarian politics that only benefit only the Dutch and the local power holders. Third, it is to ensure legal certainty concerning the residents' right to land ownership - the land which had not been used to improve the welfare of the residents (Rachman, 2017, pp. 69-70; Soemardjan, 1984, p. 106).

What is implied in the Agrarian Fundamental Law is that the state does not act as the landowner. The state, on the contrary, has a great authority to regulate and control the right to the management of natural resources (Soemardjan, 1984, p.106).

This initial spirit places the state's right to control as a means for the state to use its power to take care of the natural resources. The means must be positioned so that the people's prosperity as the main objective of the state's right to control can be achieved (Sembiring, 2016, p. 121).

For Sembiring (2016), the state's right to control should be distinguished and cannot be equated to domain rights. The core meaning of the state's right to control for Sembiring (2016) is how the state with a number of capacities and authorities formulate several policies, regulations, guidelines, management and finally supervision of everything, including those of the forestry. In line 
with Sembiring (2016), Rachman (2017) emphasises the shift of authority of domain principle to the state's right to control. Suppose the domain principle places the colonial power in the position of having the absolute authority of land ownership and land sale to just anybody, including to foreign parties that causes the birth of private land, then through the 1960 Agrarian Fundamental Law. In that case, the state's right to control is placed at the position of non-land owner. The state, as such, is endowed with the power to manage the use and preservation of lands as well as with rights of and the relation between residents as far as the land, water, and air space are concerned (Sembiring, 2016).

Within the forestry context, the state's right to control of forest is not understood as the state that owns the forest. In other words, the forest does not necessarily belong to the state. The term 'own' allows the state to use it arbitrarily so that it has an impact not on the residents' welfare but the accumulation of wealth of the state's and the private elites, as witnessed in Indonesian history (Sembiring, 2016).

Conflicts over the forest that have been taking place in Indonesia so far are considered by many as having to do with the state's right to control. The concept and practice of the state's right to control, as demonstrated by Sembiring (2016), can be negated and refuted by the communal rights of the customary people. As holders of rights to the collective forest, the local residents should be included in an open and accountable official discourse. The involvement of people, especially traditional communities, is a conditio sine qua non, a must in the rational discourse on forest management.

Furthermore, Sembiring $(2016$, p. 127) insists that other than the limitation of the state's right to control when it is confronted with the privileges of customary people, the state's right to control is also limited by two basic principles: constitution and substance.

People's dissatisfaction with the shift of state's right to control to state's monopoly, which appears in the state-market business alliance, is expressed in several social movements relatively massive throughout the country, especially in the NTT province. Therefore, I need to describe the framework of social activities in a concise manner.

\subsection{Social Movement as Arena of Resistance}

In the tradition of social sciences, a social movement is seen from different perspectives by some social scientists. On the one hand, some social thinkers see it negatively. Social theorists like Arendt (1951), Fromm (1941), Hoffer (1951), Schlesinger (1949), in Zirakzadeh's contention (Zirakzadeh, 2006, p. 6) belong to the camp that underestimates social movement and considers it as immoral and antidemocratic.

This view is similar to classic pluralism that regards social movement as irrational. Then, the classic theory of pluralism underwent a slight shift or revision into neo-pluralism since some writers gave their critiques in the 1960s. Neo-pluralism consists of two variants: theory of rational choice over protests and theory of political process in rational choice theory over demonstrations and political process theory in political opportunities (Jenkins, 1995, p. 19).

On the other hand, another group sees social actions as rational and democratic that becomes part and parcel of the resistance from victims of development. This paper takes the second position and places social movements as a rational and democratic articulation of protest from the systematically marginalised people and excluded by the state in collaboration with private investing capitalists.

Some thinkers describe social movements in relation to the state (Jenkins, 1995, p. 15). A social movement consists of collective actors marginalised and excluded from the political order by state policies. According to Jenkins' analysis, the state is a political entity in the Weberian perspective that has the only authority to apply violence to the citizens. He distinguishes two aspects of the state: the state in itself that exists through a structure of regulations or regime, and the government consists of actors who execute the policies and regulations. The social movement tries to challenge both the government actors and the state. The articulation of social movement is carried out through an intermediary group that Jenkins calls political representation system, that is, several 
institutions representing social interests. As Jenkins believes, a social movement is related to three important actors, namely, state, political representation system, and citizens (Jenkins, 1995, p. 5).

The social movement is an informal network that relies on trust and solidarity that move and prompt the emergence of issues through various forms of protests (della Porta et al., 2006, p. 19). The main characteristic of social movement is to move what della Porta calls 'common interpretation of reality, something considered potential to midwife the birth of solidarity and collective identity. The second aspect of social movement is political participation. And finally, a social movement is understood as something that emerges from an informal network that is supposed to include the plurality of actors, ranging from individuals to groups, from weak organisations up to strong and well-structured ones. Unlike political parties that give an ID card as formal proof of membership, a social movement has a very loose membership as its character. The basic characteristic of social movement membership is collective actions, without necessarily becoming a formal member of a particular organisation (della Porta et al., 2006, pp. 18-20).

There are three main features in the social movement. First, the social movement consists of people who try to construct a new social order in a radical manner. Participants involved in a social movement do not oppose the government's authoritative decisions and make a significant change within society. Second, social movement refers to political activities or actions by people with different backgrounds, most of whom come from low, middle, or non-elites. Third, the social movement contains tactics of confrontation and disruption executed through various ways, such as the occupation of buildings, business boycott, and taking to the street (Zirakzadeh, 2006, pp. 4-6).

New social movements are often distinguished from old social activities. The new social movements that emerged from 1960 to the 1970s gave attention to culture, identity and meaning for the transformation of society through cultural aspects. However, these new social movements must also be placed in political economy relations, emotions, morality, and vision to observe changes of movements in the contemporary era (Langman, 2013). Meanwhile, the old social movements referred to decent wages for workers, and the struggle was aimed at changing structural inequalities.

Since its emergence by the end of the $18^{\text {th }}$ century in Western Europe and North America, the social movement spreads worldwide in forms distinct from revolution, civil wars or military coup d'etat (Tilly, 2006, p. 182). Therefore, not all contentious politics can be categorised as a social movement. An occurrence is called social movement if it consists of three elements: campaign, repertoire, and WUNC, which stands for worthiness, unity, numbers, and commitment (Tilly \& Tarrow, 2015, p. 11; Tilly, 2008, p. 121).

In the campaign, the social movement actors make some demands that all movement groups fight for. Even, there are three constitutive components, namely "a group of self-designated claimants, some object(s) of claims, and a public of some kind" (Tilly, 2006, p. 184).

Further, the participants or people associated with social movements use movement means such as demonstrations, public meetings, petitions, public statements, and even lobbies in the repertoire. And finally, a social movement has to do with worthiness, unity, numbers and commitment (WUNC) from social movement actors.

For Tilly (2004, p. 12), the social movement described above has three claims and demands: program, identity, and standing. The program consists of support for or opposition against the

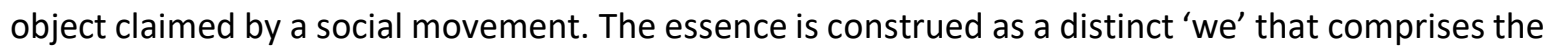
individuals involved in a social movement supported by what Tilly calls 'WUNC' - standing in the position of those whose interest is being fought for by both the minority and victims of development policies.

Social protest by social actors does not come merely from individuals' initiatives as in liberal society. Social protest is organised and mobilised by organisations, either by well-structured, formal and rigid organisations or by informal, flexible, fluid and loosely constructed organisations. As such, the initiatives for social movements come spontaneously from either individual who receives broad resonance from the beginning of a social training or mobilisation or the combination of spontaneity and mobilisation. 
In the orthodox Marxian perspective, a social movement is affected by economic production relations. But on the other hand, a social movement also involves aspects that have to do with power relations combined with a cultural approach that had already taken place in the Besipae social movement, East Nusa Tenggara province.

\section{Research methods}

This research is qualitative research that tries to trace the monopoly of forest management and how to model local people's resistance. The research was conducted in the Besipae forest area, South Amanuban subdistrict, South Central Timor Regency, NTT Province. The research period started in early 2019 to August 2020.

The researcher used several tools, including in-depth interviews, observations, and focus group discussions at the research location (Corbetta, 2003). In addition, the researcher participated in a series of discussions organised by the Indonesian Forum for Environment of NTT Branch (WALHI $\mathrm{NTT}$ ) involving Besipae solidarity activists as well as discussions that invited local Besipae residents shortly after the demonstration in Kupang, especially discussions at the WALHI NTT office and in Besipae.

The researcher also attended the food festival at Besipae, organised by the Indonesian Forum for Environment (WALHI NTT) in 2019. I watched this festival for two days and was involved in discussions with local residents.

The total number of informants is 35 persons who are directly involved with the Besipae forest conflict. The key informants for this research come from the community members who reside in the Besipae forest vicinities. A good part of the 37 households who are domiciled around the area is made resource persons. The selection of informants is based on three reasons. First, local residents live in the forest area being disputed by the residents and the provincial government. Second, they are the victims of intimidation, beatings, expulsion and depoliticisation by state politics. Third, they are the main actors of social protests both in the forest areas of South Amanuban subdistrict and in Kupang, the capital city of NTT province. The information explored from them is how the provincial government and the local elites treat their presence in the forest and how they react against this treatment in social protests.

Together with 37 households, important figures from the Association of Traditional Leaders for Truth and Justice (ITA PKK) make a constitutive part of the residents who live in the Besipae forest vicinities. Other than victims of state politics in the management of Besipae forest, ITA PKK is instrumental in voicing the social protests. They mobilise the local people around the forest to reclaim and reoccupy the forest. They even organise the victimised local people who reside within the forest vicinities to conduct rallies of social protests in Soe, the capital town of South-Central Timor regency, and in Kupang, the capital city of NTT province. As leaders of social protests and social movements, ITA PKK held meetings with the NTT House of Representatives and the provincial government, made statements for the press release, and become the new customary leaders as an antithesis against the old leaders. They tend to side with the provincial and district governments. The information explored from ITA PKK is how they can conduct a cultural movement in collaboration with street politics.

The resource persons for this research also come from the local residents who live in South Amanuban subdistrict - not in the disputed forest area - who work as cattle breeders and receive calves as assistance from the government. I dug out feedbacks from them concerning the government's assistance for the cattle breeder groups.

The informants for this research come also from the Office of Forestry and the Office of Animal Husbandry of the NTT Province. These two offices have been involved intensely in the management of the Besipae Forest since the signed contract with Australia ended in 1987. The informants of these two offices are not only those who are still active in office but also those who are already retired. These retired parties are historical actors who know the ins and outs of the field. These groups are government officials who draw up government policies over forests that result in state monopoly of forest management. What is being explored by the government are the model of forest 
management since 1982, the process of cattle breeding by local residents under government assistance, and how the government treats local residents within the forest vicinities.

In addition, other informants are the village head and village staff in the South Amanuban subdistrict, landlords from the Nabuasa clan, community leaders, cattle breeders, and the Indonesian Forum for Environment of NTT Branch (WALHI NTT). WALHI NTT is a social organisation that has long supported the victims' struggle in the forest area, assisted them and even get involved in their social protests. As such, a number of parties involved in this research, as already mentioned, are supposedly good subjects for this qualitative research project.

The research data are then analysed from the perspective of state monopoly and social movements. Therefore, to enrich the data analysis, the researcher uses a number of references taken from books, journals and mass media (printed and online) that match the research theme.

\section{Findings and Discussion}

\subsection{History of the Besipae Forest Management: perspectives from below}

The origin of Besipae forest management began with the governor of NTT, Ben Mboi, in February 1980 to Australia. On the visit, Ben Mboi looked at the modern agricultural and livestock development system in Australia. By observing in detail, the development practices, he expected that the program is developed in NTT Province for two reasons. First, the topography of the NTT region, which is mainly made up of savanna, is relatively suitable for cattle breeding. Second, to improve the economy of the people of NTT, who primarily work as farmers and cattle breeders.

The governor of NTT was followed by a meeting between the Australian side with the extended family of Nabuasa and several tribal chiefs in South Amanuban in December 1981. After going through several stages of negotiations, it was finally agreed that the livestock development project in the Besipae forest area would take place from 1982 to 1987.

The location for livestock development was the Koa forest area, a protected forest area covering an area of 2,599.17 hectares, the status of which was based on the Decree of the Minister of Forestry number 89/KPTS-II/1983. Referring to the concession certificate number 1 of January 30, 1986, issued by the Agrarian Office of South-Central Timor Regency, the size of forest area given to the Office of Animal Husbandry of the NTT Province as stated in the report of the Bureau for Economic Affairs of the NTT Provincial Secretariat (Biro Perekonomian Setda Provinsi Nusa Tenggara 2012), is 3,780 hectares. The WALHI NTT report (WALHI 2020) shows that the total forest area handed over to Australian party is 6,000 hectares. It is allocated from protected forests and communal land of people in Besipae. After the termination of the Australian work contract, livestock development and forest control projects were completely taken over by the NTT provincial government from 1987 to 2012.

This study found three problems in the area of forest management. First, the elitism of the empowerment aid network. In principle, economic empowerment is aimed at both groups and individuals who are equally vulnerable in the economic domain. The cattle breeding pattern developed by Australia and the NTT Provincial Government provided cows for parties with limited access to production resources. In practice, livestock provision tended to benefit local elites, government officials, and those from lower ranks who make contributions to government officials at the local level.

In 1984, the people of Mio village and the people of Besipae area were invited to participate in cattle development activities. The control tool used by the government was the attendance list of the participants. The government stated that the people who are present in every activity at the cattle breeding installation would receive cows. On the other hand, if the community does not attend the government's invitation for community service, then the community will not receive the assistance.

This information should make the local residents enthusiastic about participating in every activity facilitated by the provincial government. However, in practice, the government does not act fairly towards all citizens, especially those who do not have economic, political, and cultural networks. Lower class residents who work diligently in the installation area are not given priority to 
receive cows. The government tends to prioritise giving cows to anyone who gives money, handwoven fabrics, chickens, pigs, woven scarf, and other "tributes" to the government as a means of smoothing out the assistance (the Mio village FGD 1/06/2019).

More than that, a large number of cows are withdrawn from the community groups to be given to members of new groups who are in need. However, in practice, the community members who have received 'allotment' of assistance still receive cows every year as long as they are close to the installation staff, even though there are still members of the community who do not get livestock (interview with DB, head of a cattle breeders group, on 1/06/2019). With this, the government is building a dual pattern of acceptance of residents: one with special networks in the form of symbiotic mutualism and narrow patronage, another being without, that ends up in the unequal distribution of livestock.

In line with this, a member of the ITA PKK, BS (interviewed on 3/01/2019) said that livestock development in the Besipae area tends to benefit the sub-district head, police, local bureaucrats, and teachers. This group is the middle class, whose lives are mostly financed by the state, that has undergone a transformation in contemporary Indonesian politics (cf. Jati, 2014, 2015; Van Klinken, 2015). Apart from receiving the state's share, this middle class also practices small-scale exploitation of farmers and ranchers at the local level. In order not to be seen as a monopoly, government employees and other middle-class people give calves to certain people from among the common people to raise. This small community only serves as pseudo-owners, and the real proprietors are government officials.

Second, there are restrictions of access and prohibitions for residents to take forest products. Farmers and ranchers living around this area are prohibited by the provincial government from taking forest products, whether wood or grass, in the forest area, even though out of the total area of 6000 hectares handed over to Australia. There is a protected forest that belongs to both the state and the local communities. This particular part contains shrubs. This prohibition ultimately makes it difficult for residents to feed their livestock and hampers local people's agricultural activities.

The government controls the behaviour of citizens through the construction of forest area boundaries which in the Foucauldian perspective is seen as a regulatory tactic through sovereign power, disciplinary power and bio-power (cf. Lilja and Vinthagen, 2014). Residents must not violate the determined limits if they do not want to be punished. Yakob Puai, one of the heads of RT in Mio Village, was put into prison at the TTS Police detention for 21 days in the late 1990s. He was locked up in iron bars because he cut the lamtoro wood in a forest area to feed his livestock (FGD in Mio Village on 1/06/2019).

Third, apart from the elitism of empowerment assistance networks and restrictions of access to forest resources for local residents, the problem of forest management is exacerbated by the practice of clearing 1,050 hectares of forest initiated by the provincial government (WALHI 2020). In April 2008, the government implemented a reforestation program known as the forest and land rehabilitation movement (GERHAN). In this project, the NTT Provincial Office of Forestry and the community did the clearing that resulted in deforestation. Information gathered from the FGD indicated that teak, mahogany and candlenut, and other large trees were cut down. The irony is that this type of logged wood was then replanted in the same forest area (cf. Lewokeda, 2016).

This program led to dissenting opinions between the provincial government and the WALHI. On the one hand, the government claims to be running a reforestation project, although, on the other hand, the WALHI emphasises that the program is a massive forest clearing.

After the period of tree cutting and land clearing ended, the community was given the opportunity by the government to work on the land. The residents seemed enthusiastic about the chance because, after that, they could cultivate the land to plant various crops such as corn, sweet potatoes and beans. The harvest was abundant, which was very beneficial for the people at that time. However, the government allocated a cultivation period for only two years. In the third year, the government asked residents to leave the cultivated land because the land belongs to the government (FGD, Mio village, 1/06/2019).

Apart from being directly linked to the Besipae forest area, the conflict between the government and local communities is also related to the unfair distribution of land tenure in the 
South Amanuban sub-district. In the Timorese tradition (Atoin Meto), communal land cannot be sold to other people. Communal land can only be given to others to work on.

This tradition has undergone tremendous shocks since the period of agricultural modernisation in support of the green revolution policy during the Suharto era. This modernisation project led to distributing land from local elites to individuals who had access to bureaucratic capital and power. The distribution of land was carried out through a buying and selling process, as coveted by market supporters (Borras et al., 2011; Borras et al., 2012). This benefits local landowners and the urban middle class, and local government officials in land tenure.

Since the government launched the land certification program, communal lands have been divided into properties that belong to individual community members. A crucial problem was slowly emerging and intertwined. Government officials who have access to power own potential properties in Bena village, South Amanuban subdistrict (Interview with the village head of Bena, January 2020). This is evidenced by the relationship between the local government and local elites.

\subsection{Technicalisation of Domination}

After the period of forest concession ended (1987-2012), it seems that the East Nusa Tenggara provincial government is eager to continue its control of the Besipae forest areas to fulfil their political and economic interests. This research finds four essential strategies developed by the government to maintain its monopolistic power.

First, the issuance date of usufructuary certificates from 1987-2012 by the government. The issuance of this certificate gives flexibility to the provincial government to control forest areas for livestock development, even though local people experience isolation from this area. Ironically, the provincial government continues a similar practice by issuing new usage rights certificates without involving indigenous peoples and stakeholders at the local level. The issued certificate replaces the old one, arguing that the old certificate has been lost. The government takes the initiative itself in extending the use and control of forests. In fact, as the legal owner of communal land, the community must be included in the official discourse to seek approval from the community (Sembiring 2016). With this certificate, the government still has the legal right to control the forest.

Second, the government intimidated the residents who had built houses to sign a letter of agreement or contract to leave the Besipae forest area. In this forest area, a number of residents who joined the customary alliance had built a number of houses as part of a political project and historical block developed by the community. In 2019 the government forced residents to demolish these houses. Through the Civil Service Police (Pol PP), the government intimidated residents and forced them out of the houses built. The government considered that all houses built by residents in forest areas were "illegal" and demolished.

In line with this, the NTT provincial government used a number of police, civil service police and the military to demolish residents' houses in the forest areas. With a wage of Rp. 50,000 per person, the government was trying to pay local residents to tear down houses built in the forest areas in August 2020 (interview with GMKI chairman, 21/8/2020). The NTT provincial government also deployed all security forces and military forces to threaten women, children, and social protest alliances in the Besipae forest area in mid-August 2020.

As soon as the NTT provincial government mobilised all the police, civil service police, and military forces to destroy the residents' houses, the residents were forced to stay under the trees for several days. Even though the government expounded discourses on land ownership and land use and argued that they had built temporary houses, residents refused to move because the houses were built on land whose status was unclear.

Third, the creation of public discourse of "forest occupation" for people who had occupied forest areas. The NTT provincial government accused a group of people who had lived in the land and built houses in forest areas as occupants or parties who had seized the government's land. The government deliberately used the stigma of occupying or usurping someone's land to destabilise the solidarity of the community groups around the forest. The history of land use in this area is that the indigenous people handed over the land. This has placed them in an awkward position as quasiowner of the land they handed over to the provincial government in 1982. The bad impact of the 
stigma of occupation has caused the local community to be seen as foreign to the forest circle community.

Fourth, attempts to silence and spread fear to women and children who are involved in social protests. The history of the Besipae conflict was also championed by women. Women always appear at the forefront when dealing with governments who come to conflict locations and try to reclaim the land. In May 2020, a model of women's resistance was shown in the form of a topless action in front of the Governor of NTT, Viktor Bungtilu Laiskodat, and all the people present and witnessed by netizens who uploaded the event on social media.

Faced with women's theatrical actions in mid-May 2020, a member of the NTT House of Representatives, Maria Nuban Saku, and other DPRD members as well, at the DPRD session, asked the prosecutors to initiate a legal proceeding concerning the topless actions by several women in Besipae based on pornography and porno-action. Women's movements are framed as embarrassing, dishonourable, and inhuman (Expontt.com 2020). Staff at the NTT Provincial Bureau for Legal Affairs, Alex Lumba, confirmed that it would proceed to file the case or bring the case to the realm of criminal law (K Alex, 2020). This was also supported by the chairman of Commission II of the NTT Provincial DPRD from the National Democratic Party, Kasimirus Kolo. He emphasised an agreement between the government and the legislature to instigate a legal proceeding for the case of porno-action by women in Besipae (Salmon, 2020).

The legislative function of these members of the provincial House of Representatives does not refer to the actual history of land ownership. It even ignores the unilateral issuance of certificates by the government. With the threat of pornography and porno-action arguments, legislators support the government to take over land ownership (Rosary, 2020b).

The practice of controlling and disciplining citizens by the government continues up to the secondary school level of educational institutions. A common thread can bring together policy cooperation between the provincial government and the South-Central Timor district government to perpetuate the monopoly of control over forests through school institutions. School children from Besipae who are currently attending Vocational High School (SMK) are given sanctions by the school. Rejection by parents in the Besipae forest area also directly impacts children in school (Suni, 2020).

The government uses these various strategies to perpetuate forest tenure rights that benefit the politico-economic interests of the government elites. The state's right to control is reproduced in the forestry and livestock arena.

Accumulated disappointment with the government that monopolises forest management, elitism of livestock distribution networks, exclusion of local communities from access to forest resources, forest destruction by the government, and monopoly of land tenure led to social protests social movements that appear in various forms.

\subsection{Types of social protest: From Street Politics to Cultural Politics}

The social movement in Besipae is a combination of street politics and cultural politics. These two entities cannot be separated from one another. As a rational and moral movement, in contrast to the views of classical and neo-classical pluralism, political and cultural movements assume each other to achieve the targets of the struggles of those who join in social protest.

One of the social protests is street politics. The community, including the elderly, women, and children, held demonstrations in the forest area. They blocked the road connecting Malaka and Kupang on February 9, 2020. The result of this blockade was traffic jams for several hours. Consequently, residents had difficulties getting out of the forest area using vehicles (Rosary, 2020a).

The mass action of citizens also sealed off offices used by the regional government. In the Besipae forest area, several buildings are left behind by Australia, which is then used by government officials at the local level to monitor cattle raising and protect forest areas. Local people sealed these buildings. A number of civil servants who inhabit these buildings were prohibited from leaving for several days. In the end, the community urged and expelled government officials from the Besipae forest area.

After successfully driving out the government, the Association of Traditional Leaders for Truth and Justice (ITA PKK) agreed to divide the land into community members fighting with them. The 
land area divided is $20 \times 100$ meters square. The land that has been divided is inhabited and managed by residents. This is the modus operandi to prevent the government from returning to control forest areas that have been detrimental to local communities.

The street political project of the Besipae residents is staged not only in forest areas, but also on display to the government at the Governor's office and to the legislature at the NTT Provincial DPRD office. Their struggle was channelled through demonstrations. From this demonstration, they were directed to hold a number of meetings with the provincial government and legislators with only one goal, namely to return land rights to citizens.

The struggle through street politics has received support from cultural-political movements. Political legitimacy is fulfilled in cultural legitimacy as an effort to maintain solidarity among members of social movements. In principle, social movements have not tightly bound members, as is found in a very rigid political party membership. Social movements always have a fluid element of membership (della Porta et al., 2006).

Local food festivals as cultural projects were then made means of struggle to reclaim the land. This cultural project was designed to unite all the divided cultural forces into one joint force. At first, the initiative to fight against the state that controls the people's forests came from the Besipae traditional leaders.

Local cultural elites invited young leaders from the Amaf and $M e o^{1}$ circles and elements of other regional cultures to build social protests. This group then started strengthening their bond from the village level up to the central government, asking for help from the Indonesian Forum for Environment (WALHI) and members of the House of Representatives speaking for NTT in Jakarta.

However, in the process of looking for support, the cultural elite had obstacles and even betrayal. Therefore, through the food festival, social protest actors made efforts to fight against the monopoly of the government elite with great cultural power.

On March 15-16, 2019, a food festival was held in the Besipae forest area for the third time. The theme chosen at the food festival was "Haim moen natuin tetus nako nasi, talan tia haim panat nasi" [we live from forest products, so we have to protect the forest].

A food festival is a form of consolidation of the colossal power of the people to take back the forest areas from the hands of the state. In the hands of the state, the Pubabu customary forest is not proven sufficient to support the community. The state actually supports the corporation through forest concessions and simultaneously benefits the provincial government elites from cattle management. After the end of the concession period, the dominance of forest management rests with the state. The state's right to control had caused the Pubabu forests to be in a complex condition to be returned to indigenous peoples shortly after the Australian contract period ended. Communities have struggled for years to reclaim the forests. In light of this thought, food festivals are interpreted by people living in forest areas as a cultural legitimacy of communal ownership of forests.

There were three activities held at this festival-first, village discussions. A discussion is a form of the forum to spread resistance ideas and consolidate the people's powers. They discussed the history of forest tenure by indigenous peoples, the control of forests by Australia and the Indonesian government, and their struggle to take back the customary forests. They also discussed the involvement of ancestors in protecting the environment. The heroic values of the ancestors must be conveyed to the participants who were present in the forest area at the festival and the children. In addition, on the sidelines of this activity, festival participants watched films or videos of how the locals expelled the government officials living in the Besipae farm area.

On the contrary, they also witnessed the eviction of citizens by the provincial government and the street politics that they had carried out. Thus, video playing and village discussions are a form of memory recollection of their resistance. Through this festival, memories of past heroic actions were brought back to pump up the spirit of resistance and maintain the solidarity of social protest among members of social movements from various circles.

\footnotetext{
${ }^{1}$ Amaf is the second stratum in the Timor social stratification, often acting on behalf of the Usif, the first stratum, while $M e o$ is the Timor warriors sometimes hired as mercenaries in the past.
} 
Second, the presentation of the oko mama (a small woven basket containing betel nut) and a piece of hand-woven fabric. Oko mama is one of the gifts that have a significant meaning of respect to the customary elders. This series of events was continued with a traditional speech in local languages in front of the Amaf.

The structure of indigenous peoples is spoken openly in public during the festival. The structure of the Besipae customary community consists of Usif, Amaf, Meo and the commoners. Usif plays the role of the king. Amaf acts as a connector of Usif's power to ordinary people. Meo controls the government system, especially in carrying out military duties (cf. Neonbasu, 2016, p. 32; Ormeling, 1957, p. 9).

The re-pronunciation of the structure of indigenous peoples is a sign of and simultaneous recognition of the power of the cultural elite responsible for customary forests. The structure of the customary community in certain matters guarantees forest sustainability. Tracing the power structure of the Pubabu community is a form of restoring the power of the local community to take care of the Pubabu forest in a self-supporting manner. The forest is protected by the community because there is a mutual consensus that binds and limits the community from activities that damage the environment. This consensus is then guarded and watched over by the cultural elite. This festival provides a foundation for adequate appreciation and recognition of local cultural figures who are supposed to maintain consistency of choice and support for the people in defending their rights to forest areas.

Third, the forest products exhibition. The festival was held to display forest products that comprise sorghum, tubers, tamarind, honey, coconut oil, medicinal herbs, and the farmers' handicrafts. The products and crafts on display came from forests that were once considered prohibited forests, which the local language calls Kio. Therefore, the festival was considered a celebration of public gratitude to God Almighty (Usi Neno), who has given crops to sustain their lives.

Forest products had supported the Besipae people since their ancestors lived in this place long before the Dutch and Portuguese colonisers established their powers in Timor. However, the Timorese people experienced alienation of forests and forest products when the Dutch arrived in Timor. Forest products were seized from the occupied territory and brought to colonising countries. After that, the colonial control of forest metamorphosed into forest control by the post-colonial state, especially by the NTT provincial government. The forest products exhibition at this festival shows that people can freely re-manage the forest to fulfil their daily needs.

\subsection{Formation of Customary Institutions}

Adat has various meanings in accordance with the context and particular period from the colonial to the post-colonial era. In general, adat is understood as a set of unwritten rules governing specific local communities (Asriyani and Verheijen, 2020, p. 27).

From research on customary practices in Flores, Erb (2016), as quoted from Asriyani and Verheijen (2020), shows three models and applications of adat, namely adat as culture, adat as ceremonial practice or religious rites, and adat, which refers to political institutions. As a political institution, customary power is used to administer rights and control over land in Flores, East Nusa Tenggara.

The formation of customary institutions in Besipae is part of the political institutions to support social movements. Social movements are not only carried out through street actions but are also fought for through cultural movements. Citizens' struggle is carried out by forming a customary institution called the Association of Traditional Leaders for Truth and Justice (ITA PKK). This group was formed to challenge the government's monopoly in managing forests and urge the government to clarify the status of land ownership, whether it is clan-owned or government-owned, and reclaim local people's rights to forests.

This group sets some rules that everyone must obey for the sake of forest sustainability. Some of the agreements taken by this group are, first, to allot land measuring $20 \times 100$ meters square in forest areas to members who are involved in the struggle. The second is to build a house on the land that has been distributed to each resident and to oblige all members to live in the house. Third, the community is prohibited from destroying the forest. If the community violates this prerequisite, [he] 
will be given quite a heavy sanction, namely replanting 50 to 100 timber trees. Fourth, the community is not allowed to take forest products outside the time stipulated by the ITA PKK. Besipae forest products must be harvested periodically so that this forest can bring prosperity to the community.

ITA PKK divides the Besipae forest into four main parts, namely production forest area, conservation forest area, protected forest area, and residential area. This division is intended to conserve forests and anticipate arbitrary use of forest products. Forest products such as honey, tamarind, bamboo, and a number of other products have been used both for consumption and for sale to the market by the people living around the Besipae forest.

In addition to safeguarding the Besipae forest management, ITA PKK plays a role in literacy for women and children as well as all people involved in mass actions. ITA PKK assists women and children to process forest products into an added value which can then be used to support their families. Women and children are also given understanding and knowledge about the actions of social movements that must be taken to defend their rights to forests.

This group is formed to organise mass actions both in forest areas and in front of the provincial government. They prepare all the tools for social protests ranging from discussion materials, land certificate documents, ideas for audiences with the legislative bodies and the provincial government, and the people's mass action networks used during social protest actions.

Various forms of mass street actions are organised and led by this group. To build a broader mass action, this group organised social networks with multiple alliances such as WALHI NTT, the National Commission for Human Rights, Indonesian Women Solidarity, and a number of other social organisations.

Forms of social protest by the Besipae communities and some social alliances through street politics, cultural politics, and the establishment of customary institutions indicated that the Besipae social movement capitalised on the political elements and cultural elements simultaneously. Nevertheless, Tilly does not sufficiently describe this model of social movement in his works.

\section{Concluding Statements}

This paper has shown the history of the state monopoly of forest management that has benefited local elites on the one hand while excluding communities on the other in Timor, East Nusa Tenggara. Many scholars on Timor resource management suggest that local communities are the culprit of deforestation. Such narrative has been the dominant explanation of deforestation in West Timor. Unfortunately, the author found that local governments are also the driver and key actors behind deforestation.

Interestingly, the Besipae community used a cultural approach through cultural festivals in the forest area and even established a customary institution called the Association of Traditional Leaders for Truth and Justice (ITA PKK). This phenomenon demonstrated the possible combination and simultaneity of political and cultural aspects in social protests. This movement also aims to reject state domination and change the unequal state-civil relations and social order. This social protest is intended to dismantle the old socio-cultural ties that benefit the government rather than local communities.

The novelty of this article is that there is no radical separation between the cultural element and the street politics in an attempt to challenge the systemic inequality designed and controlled by the state. The cultural element is being used simultaneously with street politics to fight against state monopoly. In the political aspect, the target of their demand is the state's dominating power and its monopoly of forest management. They insist on being relativised through street politics that involve campaign, repertoire, and WUNC.

The dissatisfaction of local residents with the government's monopoly of practices encourages them to carry out social protests ranging from street politics to cultural politics. Local residents and a number of urban social alliances worked together to challenge the provincial government, represented by Governor Viktor Bungtilu Laiskodat. The persistence of these social protests eventually had to confront the provincial government that mobilised the state power of the Police, Civil Service Police and the military to intimidate local communities. 
Intimidation and violence against Besipe forest communities are the means of operationalising state power to maintain its monopoly over the Besipae forest area. The NTT provincial government has consistently argued that the Besipae forest area will be used to invest in livestock and moringa plants. Ironically, the government forgets that the history of Besipae forest management is a dark history of elitism that has excluded local people from their production resources.

Conflict of interest: The author declares no conflict of interest

Acknowledgement: This research is funded by the Institute for Research and Public Service of the Widya Mandira Catholic University in Kupang, 2020.

\section{References}

Álvarez, M. D. (2003). Forests in the time of violence: conservation implications of the Colombian war. Journal of Sustainable Forestry, 16(3-4), 47-68. https://doi.org/10.1300/J091v16n03_03

Ardhana, I. K. (2005). Penataan Nusa Tenggara Timur Pada Masa Kolonial 1915-1950. Jakarta: Rajawali Press.

Arendt, H. (1951). The Origins of Totalitarianism. New York: Harcourt, Brace.

Ataupah, H. (1992). Ekologi, Persebaran Penduduk, Dan Pengelompokan Orang Meto Di Timor Barat. Universitas Indonesia.

Biro Perekonomian Setda Provinsi Nusa Tenggara. (2012). Permasalahan Lokasi Penggemukan Sapi Di Besi Pa'e Kabupaten Timor Tengah Selatan Tahun 2012. Kupang.

Borras Jr, S. M., Hall, R., Scoones, I., White, B., \& Wolford, W. (2011). Towards a better understanding of global land grabbing: an editorial introduction. The Journal of Peasant Studies, 38(2), 209216. https://doi.org/10.1080/03066150.2011.559005

Borras Jr, S. M., Kay, C., Gómez, S., \& Wilkinson, J. (2012). Land grabbing and global capitalist accumulation: key features in Latin America. Canadian Journal of Development Studies/Revue canadienne d'études du développement, 33(4), 402-416. https://doi.org/10.1080/02255189.2012.745394

Butsic, V., Baumann, M., Shortland, A., Walker, S., \& Kuemmerle, T. (2015). Conservation and conflict in the Democratic Republic of Congo: The impacts of warfare, mining, and protected areas on deforestation. Biological conservation, 191,

266-273. https://doi.org/10.1016/j.biocon.2015.06.037

Corbetta, P. (2003). Social Research: Theory, Methods and Techniques. London: SAGE Publications.

Dako, F. X., Purwanto, R. H., Faida, L. R. W., \& Sumardi, S. (2018). Firewood and Carpentry Wood Contribution to the Communities of Mutis Timau Protected Forest, Timor Island. Jurnal Manajemen Hutan Tropika, 24(3), 166-166. https://doi.org/10.7226/jtfm.24.3.166

Erb, M. (2016). Mining and the Conflict over Values in Nusa Tenggara Timur Province, Eastern Indonesia. Extractive Industries and Society 3(2), 370-82. https://doi.org/10.1016/j.exis.2016.03.003

Expontt.com. (2020). DPRD NTT Mendesak Pelaku Proses Hukum. Retrieved July 14, 2020 (http://www.expontt.com/dprd-ntt-mendesak-pelaku-proses-hukum/).

Fromm, E. (1941). Escape from Freedom. New York: Holt, Rinehart \& Winston.

Harvey, D. (2005). A Brief History of Neoliberalism. New York: Oxford University Press.

Hoffer, E. (1951). The True Believer: Thoughts on the Nature of Mass Movements. New York: Harper \& Row.

Jati, W. R. (2014). Tinjauan Perspektif Intelegensia Muslim terhadap Genealogi Kelas Menengah Muslim di Indonesia. Islamica: Jurnal Studi Keislaman, 9(1), 1-29. https://doi.org/10.15642/islamica.2014.9.1.1-29

Jati, W. R. (2015). Less cash society: Menakar mode konsumerisme baru kelas menengah Indonesia. Jurnal Sosioteknologi, 14(2)

102-112. https://doi.org/10.5614/sostek.itbj.2015.14.2.1

Jenkins, J. C. (1995). The politics of social protest: Comparative perspectives on states and social movements. $\mathrm{U}$ of Minnesota Press. 
K Alex. (2020). Pidanakan Ibu-Ibu Bertelanjang Dada Di Besipae, Biro Hukum Setda Dinilai Kurang Kerjaan. Retrieved July 14, 2020. https://www.tajukflores.com/artikel/20200/Pidanakan-lbuibu-Bertelanjang-Dada-di-Besipae-Biro-Hukum-Setda-NTT-Dinilai-Kurang-Kerjaan-/

Van Klinken, G. (2015). The Making of Middle Indonesia: Kelas Menengah di Kota Kupang 1930an1980an. Yayasan Pustaka Obor Indonesia.

Landholm, D. M., Pradhan, P., \& Kropp, J. P. (2019). Diverging forest land use dynamics induced by armed conflict across the tropics. Global Environmental Change, 56, 86-94. https://doi.org/10.1016/j.gloenvcha.2019.03.006

Langman, L. (2013). Occupy: A new new social movement. Current Sociology, 61(4), 510-524. https://doi.org/10.1177/0011392113479749

Lewokeda, A. (2016). Masyarakat Minta Hak Kelola Hutan Adat Dikembalikan. Retrieved May 12, 2020. https://kupang.antaranews.com/berita/1122/masyarakat-minta-hak-kelola-hutanadat-dikembalikan

Lilja, M., \& Vinthagen, S. (2014). Sovereign power, disciplinary power and biopower: resisting what power with what resistance?.Journal of Political Power, 7(1), 107-126. https://doi.org/10.1080/2158379X.2014.889403

Neonbasu, G, ed. (2013). Kebudayaan: Sebuah Agenda Dalam Bingkai Pulau Timor Dan Sekitarnya. Jakarta: Gramedia.

Neonbasu, G. (2016). Citra Manusia Berbudaya: Sebuah Monografi Tentang Timor Dalam Perspektif Melanesia. Jakarta: Antara Publishing.

Ormeling, F. (1957). The Timor Problem: A Geographical Interpretation of an Underdeveloped Island. The Hague-Holland: J.B Wolters, Groningen and Martinus Nijhoff.

Parimartha, I. G. (2002). Perdagangan dan Politik di Nusa Tenggara 1815-1915. Jakarta: Perwakilan KITLV dan Penerbit Djambatan.

Peluso, N. L. (1991). The history of state forest management in colonial Java. Forest \& Conservation History, 35(2), 65-75. https://doi.org/10.2307/3983940

della Porta D, Andretta M, Mosca L, Reiter H. (2006). Globalisation From Below: Transnational Activists and Protest Networks. London: University of Minnesota Press.

Pujiono, E., Sadono, R., \& Imron, M. A. (2019a). Assessment of causes and future deforestation in the mountainous tropical forest of Timor Island, Indonesia. Journal of Mountain Science, 16(10), 2215-2231. https://doi.org/10.1007/s11629-019-5480-1

Pujiono, E., Sadono, R., Hartono, H., \& Imron, M. A. (2019b). A three decades assessment of forest cover changes in the mountainous tropical forest of Timor Island, Indonesia. Jurnal Manajemen Hutan Tropika, 25(1), 51-51. https://doi.org/10.7226/jtfm. 5.1.51

Rachman, N. F. (2017). Petani Dan Penguasa: Dinamika Perjalanan Politik Agraria Indonesia. Yogyakarta: Insist Press.

Raharjo, S.A.S., Awang S. A., Pramusinto, A., \& Purwanto, R. H. (2013). Sejarah Dominasi Negara Dalam Pengelolaan Cendana Di Nusa Tenggara Timur (History of State Domination on Cendana Management in Nusa Tenggara Timur). Journal of People and Environment, 20(1), 1-10.

Rosary, E. (2020a). Konflik Tanah Di Hutan Pubabu. Kenapa Masyarakat Adat Menolak Klaim Pemerintah?. Retrieved July 14, 2020. https://www.mongabay.co.id/2020/03/12/konfliktanah-di-hutan-pubabu-kenapa-masyarakat-adat-menolak-klaim-pemerintah

Rosary, E. (2020b). Masyarakat Adat Pubabu Tolak Klaim Pemprov NTT. Kenapa?. Retrieved July 12, 2020. https://www.mongabay.co.id/2020/05/21/masyarakat-adat-pubabu-tolak-klaim-lahanpemprov-ntt-kenapa/

Salmon, T. (2020). Aksi Telanjang Pemprov NTT Bakal Polisikan Warga Besipa'e TTS. Retrieved August 8, 2020. https://voxntt.com/2020/05/13/aksi-telanjang-pemprov-ntt-bakal-polisikanwarga-besipae-tts/62864/

Schlesinger, A. M. (1949). The Vital Center: The Politics of Freedom. Boston: Houghton Mifflin.

Sembiring, J. (2016). Hak menguasai negara atas sumber daya agraria. BHUMI: Jurnal Agraria dan Pertanahan, 2(2), 119-132. https://doi.org/10.31292/jb.v2i2.65

Soemardjan, S. (1984). Land Reform di Indonesia. In Dua Abad Penguasaan Tanah: Pola Penguasaan Tanah Pertanian di Jawa dari Masa ke Masa, edited by Sediono M.P. Tjondronegoro dan 
Gunawan Wiradi. Jakarta: Yayasan Obor Indonesia-Gramedia.

Suni, E. K. (2020). Dianggap Melawan, Anak Korban Penggusuran Di Pubabu NTT Dikeluarkan Dari Sekolah. Retrieved August 24, 2020. https://regional.inews.id/berita/dianggap-melawananak-korban-penggusuran-di-pubabu-ntt-dikeluarkan-dari-sekolah

Tilly, C. (2004). Social Movement 1768-2004. London: Paradigm Publishers.

Tilly, C. (2006). Regimes and Repertoires. New York: The University of Chicago Press.

Tilly, C. (2008). Contentious performances. Cambridge University Press.

Tilly, C., \& Tarrow, S. G. (2015). Contentious Politics. New York: Oxford University Press.

Usbobo, Y. V. L. (2019). BUNUK: PENGETAHUAN DAN PRAKTEK ATONI-METO DALAM TATA KELOLA HUTAN. Lumen Veritatis: Jurnal Filsafat dan Teologi, 10(1), 83-96. https://doi.org/10.30822/lumenveritatis.v10i1.209

Asriyani, H., \& Verheijen, B. (2020). Protecting the Mbau Komodo in Riung, Flores: Local Adat, National Conservation and Ecotourism Developments. Forest and Society, 4(1), 20-34. https://doi.org/10.24259/fs.v4i1.7465

WALHI. (2020). Kronologi Konflik Masyarakat Pubabu Dengan Pemerintah Provinsi Nusa Tenggara Timur. Kupang.

Yasmi, Y., Kelley, L. C., \& Enters, T. (2013). Community-outsider conflicts over forests: Perspectives from Southeast Asia. Forest Policy and Economics, 33, 21-27. https://doi.org/10.1016/j.forpol.2012.05.001

Zirakzadeh, C. E. (2006). Social Movement in Politics: A Comparative Study Expanded Edition. New York: Palgrave Macmillan. 